\title{
Causative Relationship between Domestic Investment in Jordan and Some Economic Variables during the Period (2000-2016)
}

\author{
Talal Bataineh $^{1}$ \\ ${ }^{1}$ Faculty of Business, Tafila Technical University, At-Tafila, Jordan \\ Correspondence: Talal Bataineh, Faculty of Business, Tafila Technical University, P.O. Box179, Tafila, 66110, \\ Jordan. E-mail: bataineh.talal@yahoo.com
}

Received: April 4, 2018

Accepted: April 27, 2018

Online Published: May 10, 2018

doi:10.5539/ijef.v10n6p112

URL: https://doi.org/10.5539/ijef.v10n6p112

\begin{abstract}
This study aimed at revealing the reciprocal role of the domestic investment in Jordan in affecting and being affected by some economic variables. The researcher used the appropriate statistical analysis by using (ols) way and the (e-views) program. The study concluded a group of results, the most important of which is that the domestic investment affects and is affected by the gross domestic product as being one of its components. The domestic investment also did not have a positive role in the increase of the magnitude of national exports. The study concluded a group of recommendations, the most important of which is the increase of concern about domestic investment and the increase of incentives to productive sector as they are important in reducing the problems of both poverty and unemployment.
\end{abstract}

Keywords: domestic investment, gross domestic product, inflation rate, exports magnitude, Jordan

\section{Introduction}

Jordan has a special concern about investment and the improvement of the investment environment as being a basic support for the achievement of development of the citizen's living circumstances and decrease of unemployment rates, beside its role in the improvement of the balance of trade in Jordan through its role in the increase of national exports and decrease of the magnitude of imports.

Jordan has conducted some improvements on the economic and legislative environment for the settlement of domestic investors. The great developments and changes which the world has witnessed recently, have undergone a wave of economic liberalization, free foreign trade and elimination of the obstacles which hinder the movement of capital. These developments have led to the open economies of countries with each other. Several countries have implemented reform programs and economic and legislative restructuring with the aim of achieving economic stability, overcoming fluctuations and freeing commerce and capital movement for the sake of providing the appropriate capital environment.

Jordan has taken important steps and measures concerning the release and blending of economy with international ones through the implementation of economic reform programs and the adaptation of a number of important economic legislations which have had a role in the improvement of the investment climate in general. The Jordanian experience in the economic trade fields during the past few years, has been characterized by qualitative transfer in the contribution of the private sector to the achievement of the required economic growth through the provision of a package of legislations which govern the environment of investment, in addition to the developed infrastructure through the establishment of qualified industrial zones and free areas and the holding of trade deals and Jordanian's starting the program of partnership between public and private sectors in 2008. This program is considered as the main core of the strategy of economic development adopted by the government and which emphasized the necessity for improving and increasing the services offered by the government through the attraction of the investments and experiences of the private sector.

\section{Theoretical Frame and Literature Review}

Investment is considered as one of the cores on which the national economy is based. Countries seek to maintain the magnitude and development of investment in order to reach development, prosperity and sustainable development. In this study, emphasis will be on domestic investment and its role in economic development and the aims hoped to be achieved at the domestic level on one hand and the impact on some entire economic 
variables on the other hand. Investment can be defined as sacrificing the resources used in the present for the sake of obtaining revenues or interests during a period of time in the future, as the return will be bigger than the preliminary expenditures of investment.

\subsection{Importance of Domestic Investment}

The importance of domestic investments lies in a group of things (Al-Shukeiri, 2012), the important of which are:

1) Increase in production and productivity, in a way that leads to the increase in national income, rise in the individual's average share from it and the improvement of the citizen's living standard.

2) Providing services for citizens and investors.

3) Providing job opportunities and lessening unemployment rates.

4) Increasing the rates of capital formation of the government.

5) Providing different specializations of technicians, managers and skillful workers.

6) Producing accommodates and services which satisfy citizens and exporting the surplus abroad, in a way that provides necessary foreign currencies for buying instruments and machines and increasing the capital formation. For stimulating the domestic investor and settling his investments, a group of factors should be available, the most important of which is the availability of necessary infrastructure of investment and offering it to investors with suitable prices to make it possible for domestic productive investments to produce immediately with suitable costs which are competitive in the market.

\subsection{Literature Review}

Conducted a study about the obstacles of capital formation in the industrial sector in Toolkarm Government. The study concluded the existence of a group of obstacles which restricted the capital formation in this sector and they differed in importance, namely, industrial establishments did not encounter all the obstacles determined by the study. The study recommended the necessity for the industrial establishment to follow modern managerial methods and check the procedures of specifications and measures in a way that serves the industry, and concern about the law of taxes and its role in the encouragement of domestic investment (Abu Obeidah, 2014).

Conducted a study about the impact of domestic investment in the projects of infrastructure on the economic growth in the Sudan during the period (2000-2012). The study concluded the existence of weak investment in the infrastructure in the Sudan in regard to domestic product and the financing of the infrastructure projects greatly depended on the private sector, and the investment in the infrastructure was concentrated, with a bigger ratio, on the item of capital machines. The study recommended the creation of alternative resources for financing this sector like the use of the system of partnership with the private sector in particular, in the vital domains such as agriculture, industry and mining of metals (Al-Ali, 2016).

Conducted a study about the role of regional groups in supporting the domestic investment. The study concluded several things the most important of which are the participation of regional groups in domestic economic guidance by taking their opinions, the use of modern technological means, providing encouraging initiatives for the participation of civil community and acquainting them with the importance extent of their support of domestic investments and rapid passing of special regulations of investment (Huddud, 2013).

Conducted a study about the impact of economic variables on direct domestic investment in Algiers a measurement study for the period (1989-2009). The study concluded that the size of gross capital formation passed a stage characterized by growth with positive rates, in which the prices of effective interest fluctuated before and after the economic reforms followed in Algiers. Direct investment is affected by the volume of population and is negatively affected by the price of effective interest. The study recommended the emphasis on the rate of economic growth in way that ensures the continuity of the power of effective demand in order to stimulate direct domestic investment (Hussein \& Abbadi, 2013) .

Conducted a study about the use of VR models in prediction and the study of causative relationship between domestic product and the entire capital formation in Syria. The study concluded that the gross domestic product is considered as one of the important economic indicators for any country as it reflects the entire activity and its economic performance in a certain year and which, in its turn, is reflected on the general economic situation of the country. In other ways, the gross domestic product is characterized by mutual relationship with the size of capital investments. As these investments increase, their efficiency increases as does the gross domestic product. Domestic product affects the size of investment as it is part of the gross domestic product (Nakkar \& A-awwad, 2012). 
Conducted a study about the limitations of domestic investment in Turkey- a measurement study for the period (1970-2011). The study concluded a group of results, the most important of which are the existence of a positive relationship between economic growth, domestic savings, public expenditure, rates of stable prices, and direct foreign investment on domestic investment in the long run. And the causative relationship supported this trend. The study recommended the implementation of further incentives to the foreign investor by expanding expenditure and concern about putting a suitable mechanism for the stability of exchange and the necessity for the achievement of high domestic saving rates as being a main resource for financing the escalating rates of domestic investment (Sumadi \& Thnoon, 2014).

Conducted a study about investment in the Arab Syrian Republic. The study concluded the advantage of available development economic opportunities. This can happen through the social and service development of all the areas and development of economic activities without concentration on one sector. The study also concluded the concern about human development and furthering the competence of human capital through training, education and health in order to enable the trained workers to deal with the factors of economy with competence and efficiency. It also conclude the necessity for economic reforms in Syria at all levels, especially the legislative and legal ones. The low incomes and low savings in Syria did not contribute to the formation of necessary capital in economic development (Abduljundi \& Bawadikgi, 2010).

Conducted a study about the role of the commission of investment motivation in encouraging the domestic and foreign investment in Palestine. The study concluded that most companies owning the investment projects were private contributing ones in regard to their legal formation, and most invested capital was self- capital. Most investments were concentrated on the borders of Gaza and the rest was in north, middle and south the strip. Most of these projects were industrial, tourist, agricultural and services. The study also concluded the need for some improvements relating to the rapid course of investors handlings. It also concluded that the commission did not give feasibility study services of the investment projects, not giving technical advice to investors, not helping, in giving entry and exit permissions not doing activities follow- up for technical things relating to development. It also concluded the need for training employees and opening offices in foreign countries and updating the organizational structure of the commission and issuing a guidebook for investment in Palestine (Muhammad \& Migdad, 2008).

\section{Method}

Jordan is not a big country in the Middle East Region. It has limited resources, but due to the economic policies, Jordan has witnessed development in the field of domestic and foreign investment as a result of supporting laws of investment by eliminating all obstacles which hinder investors. Table (1) shows the development of the magnitude of domestic investments in Jordan.

Table 1. Development of the volume of domestic investments in Jordan in millions during the period (2000-2016)

\begin{tabular}{lc}
\hline year & Size of domestic investment (in millions) \\
\hline 2000 & 1266.6 \\
2001 & 1235.8 \\
2002 & 1287.3 \\
2003 & 1490.8 \\
2004 & 2005.4 \\
2005 & 2733.7 \\
2006 & 2717.1 \\
2007 & 3334.1 \\
2008 & 4352.4 \\
2009 & 4584.4 \\
2010 & 5113.9 \\
2011 & 5109.9 \\
2012 & 4705.9 \\
2013 & 4739.4 \\
2014 & 5034.3 \\
2015 & 5189.1 \\
2016 & 5270.0 \\
\hline
\end{tabular}

Source: Central Bank of Jordan Statistical Bulletin. 
Through Table 1 we notice the big growth in the magnitude domestic investments during the period of the study. They increased from (1266.6) millions in 2000 to reach (5270) in 2016. This increase is due to the attracting climate of investment and the political and economic stability characterizing Jordan.

In this study, the researcher examined the relationship between some of the entire economic variables and domestic investment considering some variables like inflation rate, nominal gross domestic product, unemployment rate and volume exports and domestic investment, taking into account that some studies proved the mutual effect of these variables on each other as the domestic investment is one of the components of domestic product. For achieving the aim of the study, the researcher designed the following statistical model:

$$
D I=a_{0}+a_{1} n G D P+a_{2} i N F+a_{3} E X T
$$

Study variables: based on the economic literature, some variables believed by the researcher as being affecting and affected by domestic investment in Jordan during the period of the study were adopted as follows:

1) Nominal domestic product.

2) Inflation rate.

3) Magnitude of exports.

The first design of the study model was as follows:

$$
D I=a_{0}+a \ln G D P+a_{2} i N F+a_{3} E X T
$$

Where:

DI means domestic investment (dependent variable)

nGDP means nominal gross domestic (independent variable)

iNF means inflation rate (independent variable)

EXT means size of national exports (independent variable)

OLS method was used in the analysis through ( e- views) program. The results were as follows:

$$
\mathrm{DI}=0.781 \mathrm{nGDP}-182.9 \mathrm{iNF}+0.0009 \mathrm{EXT}
$$

$\begin{array}{llll}\mathrm{T} & 1.572 & -2.211 & 5.66\end{array}$

$\mathrm{R} 2=0.94$

Adjusted R2 $=0.92$

D.W. $=1.78$

F stoof $=67.33$

The value of stable $\left(\mathrm{a}_{0}\right)$ was excluded as being insignificant, and through analysis, it was revealed that there was:

1) A positive relationship between the increase of the volume of gross domestic product and the magnitude of domestic investment.

2) A negative relationship between the rates of inflation and domestic investment, as when the rates of inflation rise, the volume of domestic investments decreases.

3) A positive relationship between the magnitude of national exports and the volume of domestic investment, as when the magnitude export increases, the magnitude of domestic investments increases.

All the variables of the study were significant with a statistical significance. This is notices through the values of (T) and (F) and also through the value of (D.W.).

After that, a second model was built considering the domestic investment as an independent variable as in the following model:

$$
N G D P=a_{0}+b_{1} D I+a_{2} i N F+a_{3} E X T
$$

Where:

nGDP means nominal gross domestic (dependent variable)

DI means domestic investment

iNF means inflation rate

EXT means national exports size

The results were as follows: 


$$
n G D P=1.65 D I-182.9950 .6 i N F+0.0056 E X T
$$

$\begin{array}{llll}\mathrm{T} & 2.73 & -6.64 & 33.30\end{array}$

$\mathrm{R} 2=0.965$

Adjusted R2 $=0.960$

D.W. $=1.75$

Through the analysis, it was revealed that there was a:

1) Positive relationship between the volume of domestic investment and the volume of nominal domestic product.

2) Negative relationship between the rates of inflation and the volume of gross domestic product.

3) Positive relationship between the volume of national exports and the volume of gross domestic product, as the increase in the magnitude exports contributions to the increase in the volume of gross domestic product. All the variables of the study were statistically significant. This can be noticed through the values of (T) and also through the value of (D.W.).

After that, a third model was designed as follows:

$$
E X T=a_{0}+a_{1} n G D P+a_{2} D I+a_{3} i N F
$$

Where:

EXT means national exports size (dependent variable)

nGDP means nominal gross domestic

DI means domestic investment

iNF means inflation rate

After analysis, the results were as follows:

$$
\begin{array}{cccc}
E X T=179.4 n G D P & -182.9950 .6315 .5 & D I+177.8 i N F \\
\mathrm{~T} & 33.738 & -3.01 & 8.10
\end{array}
$$

$\mathrm{R} 2=0.95$

Adjusted R2 $=0.96052$

D.W. $=1.7584$

It was revealed that there was a:

- Strong positive relationship between the increase of the volume of domestic product and the magnitude of national exports.

- Negative relationship between domestic investment and the magnitude of national exports that can be attributed to the fact that most domestic investments are directed to the sectors of services, not to the sectors prepared for exportation.

- $\quad$ Positive relationship between inflation rates and the magnitude of national exports, which was in contrast to what was expected. This explains that the inflation rates in Jordan were satisfactory and did not have an effect on the magnitude of national exports. All the study variables were significant with statistical significance. This can be noticed through the values of (T) and (D.W.).

Through what has previously been discussed, we can reach the following results and recommendations

\section{Results}

\subsection{Conclusions}

1) Domestic investment is affected by and affects the variables of study; it was clearly affected by the nominal gross domestic product and also the nominal gross domestic investment. This conformed with the economic theory which states that domestic investment is part of domestic product.

2) Inflation rate is no longer negative on domestic investment, namely, the increase of inflation rates contributes to the fall of domestic investment. This result conforms with the economic literature, as the investor seeks to find a politically and economically stable environment, because the fluctuations of prices have a negative role in the volume of investments. 
3) National exports had a positive role in the volume of domestic product, while the effect of domestic investment was negative in the national exports. This can be explained by the fact that most domestic investments are concentrated on the sector of services and the non-exporting sectors. Therefore, their effect was negative.

\subsection{Recommendations}

1) The necessity for the concern about domestic investment as this sector effectively growth in the country, as well as lessening economic problems like poverty and unemployment.

2) The necessity for directing domestic investment toward the vital sectors by providing further incentives to these investments to enable them to increase the magnitude of national exports and lessen the volume of imports.

3) Simplification of licensing procedures and necessary approvals in order to start domestic projects with the necessity for offering advice to domestic investors and directing them toward the sectors in which there are the best opportunities of investment.

4) Conducting further studies about this topic by examining new variables.

5) The necessity for the concern about all the aspects which serve the investment process as it is the most fluctuating component of domestic product as it is affected by a lot of factors such as taxes, general level of prices and the economic and political situation of the country..

\section{References}

Abdulbassit, H. (2013). The Role of Regional Groups in the Support of Domestic Investment. Published master Thesis, Kassidy Mirbaa University, Algiers.

Al-Nakkar, O., \& Al-Awwad, M. (2012). The use of (VAR) models in Prediction and the study of causative Relationship between the Domestic product and the Entire Capital Formation in Syria. Magazine of Damascus University for Economic and Legal Sciences, 28(2).

Central Bank of Jordan. Annual Reports.

Department of General Statistics. Statistical Bulletins.

Khuzama, A. A., \& Abdulraheem, B. (2010). Investment in the Arab Syrian Republic. Damascus University Magazine for Economic and Legal Sciences, 26(2).

Lu'ei, F. M., \& Muhammad, I. M. (2008). The Role of the Commission of Investment Encouragement in Encouraging Domestic and Foreign investment in Palestine- A study case of Gaza Strip. Published Master Thesis, Islamic University, Gaza.

Mei, M. A. (n. d.). The Impact of Domestic Investment in the Infrastructure Projects on the Economic Growth on Al-Sudan During the period (2000-2012). Magazine of Economic Sciences, 17(2).

Moussa Al-shukeiri, el al. (2012). Managing Investment (1st ed.). Dar Al- Masseerah, Amman.

Mustafa, F. H., \& Marwan, T. (2014). Limitations of Domestic Investment in turkey- A measurement study for the period (1970-2011). Al- Rafidein Development Magazine, 36(116).

Omar, A. O. (n. d.). Obstacles of Capital formation in the Industrial Sector in Toolkarm Government. Magazine of Jerusalem University for Economic Sciences, (1).

Raheem, H., \& Muhammad, A. (2013). The Impact of Economic Variables on the Direct Domestic Investment in Algiers: A Measurement Study for the period (1989-2009). Studies for Managerial Sciences, 4(2). 


\section{Appendix A}

Study Variables

\begin{tabular}{lrccc}
\hline year & nGDP & DI & inF & EXT \\
\hline 2000 & 5998.6 & 1266.6 & 0.7 & 1080.8 \\
2001 & 6363.8 & 1235.8 & 1.8 & 1352.4 \\
2002 & 6794.0 & 1287.3 & 1.8 & 1556.7 \\
2003 & 7228.7 & 1490.8 & 2.3 & 1647.7 \\
2004 & 8090.7 & 2005.4 & 2.6 & 2306.6 \\
2005 & 8925.4 & 2733.7 & 3.7 & 2570.2 \\
2006 & 10675.4 & 2717.1 & 6.3 & 2929.3 \\
2007 & 1231.4 & 3334.1 & 4.7 & 3183.7 \\
2008 & 15593.4 & 4352.4 & 14.0 & 4431.1 \\
2009 & 16912.2 & 4584.4 & -0.7 & 3579.2 \\
2010 & 18762.0 & 5113.9 & 4.8 & 4216.9 \\
2011 & 20476.6 & 5109.9 & 4.2 & 4805.9 \\
2012 & 21965.5 & 4705.9 & 4.5 & 4749.5 \\
2013 & 23851.6 & 4739.4 & 4.8 & 4805.2 \\
2014 & 2543.1 & 5034.3 & 2.9 & 5163.0 \\
2015 & 26637.4 & 5189.1 & -0.9 & 4797.6 \\
2016 & 27444.8 & 5270.2 & -0.8 & 4396.5 \\
\hline
\end{tabular}

Source: central bank of Jordan -statistical report.

\section{Appendix B}

Table B1.

Dependent Variable: DI
Method: Least Squares
Date: 03/20/18 Time: 09:26
Sample (adjusted): 2001 2016

Included observations: 16 after adjustments

\begin{tabular}{lllll}
\hline Prob. & t-Statistic & \multicolumn{1}{c}{ Std. Error } & Coefficient & Variable \\
\hline 0.1418 & 1.572661 & 0.471613 & 0.741687 & D(NGDP) \\
0.0472 & -2.211113 & 79.38691 & -175.5334 & INF \\
0.0001 & 5.660808 & 0.000166 & 0.000937 & EXT \\
0.8304 & -0.218917 & 337.2046 & -73.81970 & C \\
\hline 3615.856 & Mean dependent var & 0.943923 & R-squared \\
1568.302 & S.D. dependent var & 0.929904 & Adjusted R-squared \\
15.10781 & Akaike info criterion & 415.2192 & S.E. of regression \\
15.30096 & Schwarz criterion & 2068884. & Sum squared resid \\
15.11770 & Hannan-Quinn criter. & -116.8625 & Log likelihood \\
1.780908 & Durbin-Watson stat & 67.33037 & F-statistic \\
& & 0.000000 & Prob(F-statistic) \\
\hline
\end{tabular}

Dependent Variable: DI

Method: Least Squares

Date: 03/20/18 Time: 09:31

Sample (adjusted): 20012016

Included observations: 16 after adjustments

\begin{tabular}{lllll}
\hline Prob. & t-Statistic & Std. Error & Coefficient & Variable \\
\hline 0.0842 & 1.869723 & 0.418184 & 0.781887 & D(NGDP) \\
0.0202 & -2.646309 & 69.13124 & -182.9426 & INF \\
0.0000 & 8.498102 & 0.000107 & 0.000911 & EXT \\
\hline 3615.856 & Mean dependent var & 0.943699 & R-squared \\
1568.302 & S.D. dependent var & 0.935037 & Adjusted R-squared \\
14.98679 & Akaike info criterion & 399.7255 & S.E. of regression \\
15.13165 & Schwarz criterion & 2077146. & Sum squared resid \\
14.99421 & Hannan-Quinn criter. & -116.8944 & Log likelihood \\
& & 1.816805 & Durbin-Watson stat \\
\hline
\end{tabular}




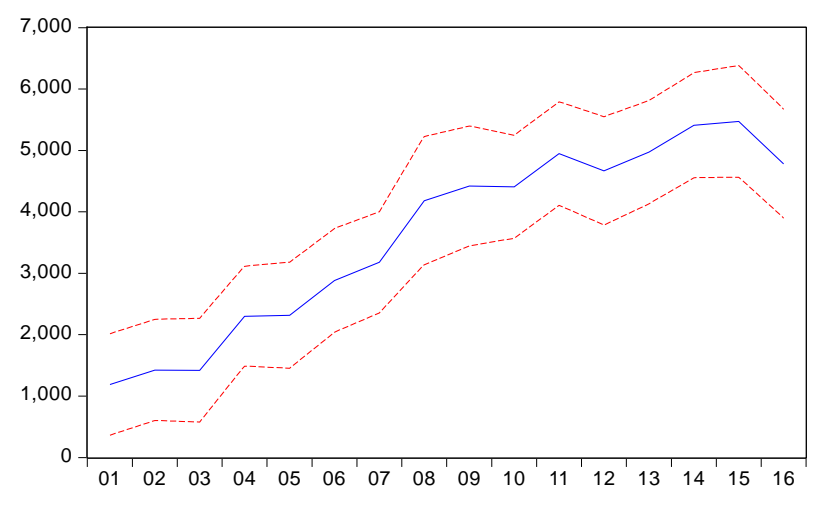

\begin{tabular}{ll}
\hline Forecast: DIF \\
Actual: DI \\
Forecast sample: 20002016 \\
Adjusted sample: 20012016 \\
Included observations: 16 \\
Root Mean Squared Error & 360.3077 \\
Mean Absolute Error & 284.5635 \\
Mean Abs. Percent Error & 8.944913 \\
Theil Inequality Coefficient & 0.046034 \\
$\quad$ Bias Proportion & 0.000377 \\
$\quad$ Variance Proportion & 0.028317 \\
$\quad$ Covariance Proportion & 0.971306 \\
\hline
\end{tabular}

- DIF ----. \pm 2 S.E.

Figure 1.

Table B2.

\begin{tabular}{|c|c|c|c|c|}
\hline \multicolumn{5}{|c|}{ Dependent Variable: NGDP } \\
\hline & & \multicolumn{3}{|c|}{ Method: Least Squares } \\
\hline & & Date: $03 / 20 / 18$ & Time: 09:37 & \\
\hline & & \multicolumn{3}{|c|}{ Sample (adjusted): 20022016} \\
\hline & \multicolumn{4}{|c|}{ Included observations: 15 after adjustments } \\
\hline Prob. & t-Statistic & Std. Error & Coefficient & Variable \\
\hline 0.0400 & 2.327462 & 0.626523 & 1.458209 & $\mathrm{D}(\mathrm{DI}, 2)$ \\
\hline 0.0001 & -5.948342 & 150.7779 & -896.8783 & INF \\
\hline 0.0000 & 17.98241 & 0.000323 & 0.005816 & EXT \\
\hline 0.3064 & -1.072587 & 1318.798 & -1414.527 & $\mathrm{C}$ \\
\hline 16728.41 & \multicolumn{2}{|c|}{ Mean dependent var } & 0.968965 & $\mathrm{R}$-squared \\
\hline 7410.173 & \multicolumn{2}{|c|}{ S.D. dependent var } & 0.960500 & Adjusted R-squared \\
\hline 17.65081 & \multicolumn{2}{|c|}{ Akaike info criterion } & 1472.737 & S.E. of regression \\
\hline 17.83962 & \multicolumn{2}{|c|}{ Schwarz criterion } & 23858494 & Sum squared resid \\
\hline 17.64880 & \multicolumn{2}{|c|}{ Hannan-Quinn criter. } & -128.3811 & Log likelihood \\
\hline \multirow[t]{7}{*}{1.870582} & \multirow{2}{*}{\multicolumn{2}{|c|}{ Durbin-Watson stat }} & 114.4777 & F-statistic \\
\hline & & & 0.000000 & Prob(F-statistic) \\
\hline & & \multicolumn{3}{|c|}{ Dependent Variable: NGDP } \\
\hline & & \multicolumn{3}{|c|}{ Method: Least Squares } \\
\hline & & Date: $03 / 20 / 18$ & Time: 09:38 & \\
\hline & & \multicolumn{3}{|c|}{ Sample (adjusted): 20022016} \\
\hline & \multicolumn{4}{|c|}{ Included observations: 15 after adjustments } \\
\hline Prob. & t-Statistic & Std. Error & Coefficient & Variable \\
\hline 0.0181 & 2.733949 & 0.603916 & 1.651074 & $\mathrm{D}(\mathrm{DI}, 2)$ \\
\hline 0.0000 & -6.644854 & 143.0726 & -950.6966 & INF \\
\hline 0.0000 & 33.80414 & 0.000163 & 0.005515 & EXT \\
\hline 16728.41 & \multicolumn{2}{|c|}{ Mean dependent var } & 0.965719 & R-squared \\
\hline 7410.173 & \multicolumn{2}{|c|}{ S.D. dependent var } & 0.960005 & Adjusted R-squared \\
\hline 17.61695 & \multicolumn{2}{|c|}{ Akaike info criterion } & 1481.940 & S.E. of regression \\
\hline 17.75856 & \multicolumn{2}{|c|}{ Schwarz criterion } & 26353754 & Sum squared resid \\
\hline \multirow[t]{2}{*}{17.61544} & \multirow{2}{*}{\multicolumn{2}{|c|}{ Hannan-Quinn criter. }} & -129.1271 & Log likelihood \\
\hline & & & 1.756778 & Durbin-Watson stat \\
\hline
\end{tabular}




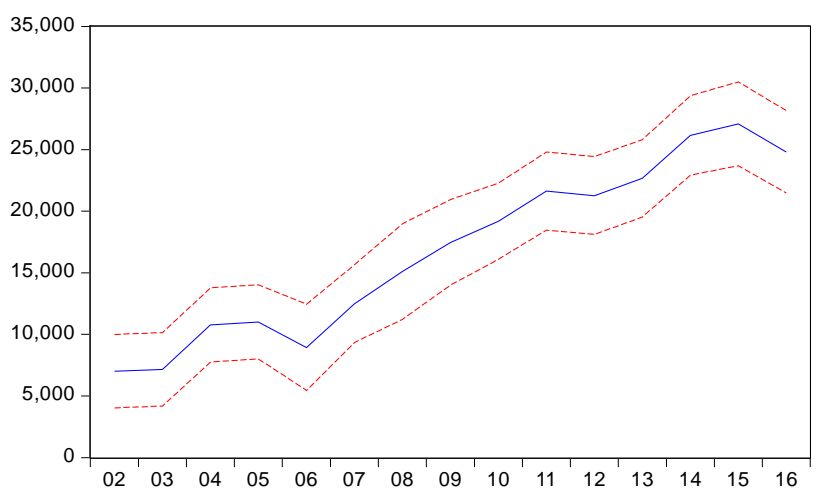

Forecast: NGDPF

Actual: NGDP

Forecast sample: 20002016

Adjusted sample: 20022016

Included observations: 15

Root Mean Squared Error $\quad 1325.487$

Mean Absolute Error $\quad 1031.192$

Mean Abs. Percent Error $\quad 7.767099$

Theil Inequality Coefficient $\quad 0.036471$

Bias Proportion $\quad 0.007872$

Variance Proportion $\quad 0.095787$

Covariance Proportion $\quad 0.896341$

Figure 2.

Table B3.

Dependent Variable: EXT

Method: Least Squares

Date: 03/20/18 Time: 09:39

Sample (adjusted): 20022016

Included observations: 15 after adjustments

\begin{tabular}{lllll}
\hline Prob. & t-Statistic & \multicolumn{1}{c}{ Std. Error } & Coefficient & Variable \\
\hline 0.0000 & 17.98241 & 9.247727 & 166.2964 & NGDP \\
0.0445 & -2.266930 & 106.8548 & -242.2322 & D(DI,2) \\
0.0001 & 5.761473 & 26120.31 & 150491.4 & INF \\
0.1211 & 1.680225 & 209082.5 & 351305.7 & C \\
\hline 3675957. & Mean dependent var & 0.967617 & R-squared \\
1226722. & S.D. dependent var & 0.958785 & Adjusted R-squared \\
27.91181 & Akaike info criterion & 249041.7 & S.E. of regression \\
28.10062 & Schwarz criterion & $6.82 \mathrm{E}+11$ & Sum squared resid \\
27.90980 & Hannan-Quinn criter. & -205.3385 & Log likelihood \\
1.875552 & Durbin-Watson stat & 109.5617 & F-statistic \\
& & 0.000000 & Prob(F-statistic) \\
\hline
\end{tabular}

Dependent Variable: EXT

Method: Least Squares

Date: 03/20/18 Time: 09:41

Sample (adjusted): 20022016

Included observations: 15 after adjustments

\begin{tabular}{llcll}
\hline Prob. & t-Statistic & \multicolumn{1}{c}{ Std. Error } & Coefficient & Variable \\
\hline 0.0000 & 33.80414 & 5.307818 & 179.4262 & NGDP \\
0.0107 & -3.018759 & 104.6139 & -315.8042 & D(DI,2) \\
0.0000 & 8.105882 & 21936.94 & 177818.3 & INF \\
3675957. & Mean dependent var & 0.959306 & R-squared \\
1226722. & \multicolumn{2}{l}{ S.D. dependent var } & 0.952524 & Adjusted R-squared \\
28.00692 & Akaike info criterion & 267291.4 & S.E. of regression \\
28.14853 & Schwarz criterion & $8.57 \mathrm{E}+11$ & Sum squared resid \\
28.00541 & Hannan-Quinn criter. & -207.0519 & Log likelihood \\
& & 1.842921 & Durbin-Watson stat \\
\hline
\end{tabular}




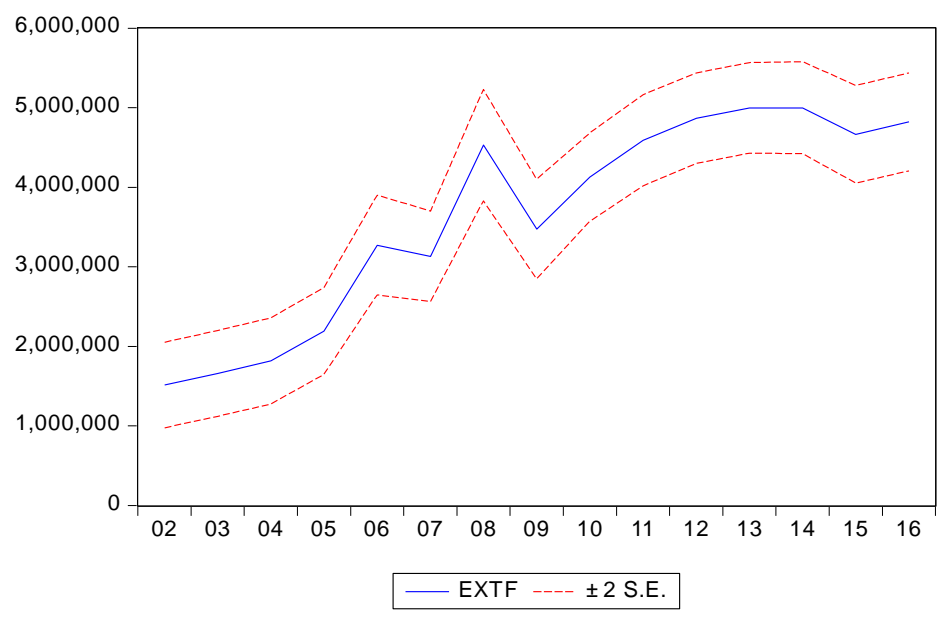

\section{Forecast: EXTF}

Actual: EXT

Forecast sample: 20002016

Adjusted sample: 20022016

Included observations: 15

Root Mean Squared Error

Mean Absolute Error

Mean Abs. Percent Error

Theil Inequality Coefficient 0.030979

Bias Proportion

0.019317

Variance Proportion

0.101177

Covariance Proportion

Figure 3.

\section{Copyrights}

Copyright for this article is retained by the author(s), with first publication rights granted to the journal.

This is an open-access article distributed under the terms and conditions of the Creative Commons Attribution license (http://creativecommons.org/licenses/by/4.0/). 